\title{
THE NEXUS OF COMPETITION FREEDOM AND THE EFFICIENCY OF MICROFINANCE INSTITUTIONS
}

- Hafezali Iqbal Hussain, Sebastian Kot, Fakarudin Kamarudin, Wong Che Mun

\begin{abstract}
The main purpose of this paper is to examine the effects of regulatory efficiency and market openness, two dimensions of competition freedom, on the efficiency of microfinance institutions (MFIs) in both its social and financial aspects. In addition, this study also examines the specific determinants of MFIs and macroeconomic conditions, two other potential variables that may influence MFIs efficiency. Within this study, two stages of analysis were conducted. In the first stage, the data envelopment analysis (DEA) approach was applied to measure the MFIs' efficiency level, while in the second phase, a panel multiple regression analysis was employed to examine the effect of competition freedom and other determinants on MFIs efficiency. The results suggest that during the study period the main reason for MFIs inefficiency is both social and financial managerial inefficiency. The management of the MFIs failed to utilize their resources fully, leading to waste of resources. Nevertheless, the MFIs had been operating on a relatively optimal scale. In addition, the level of financial efficiency in MFIs was found to be significantly higher than social efficiency. In examining the impact of competition freedom, the freedom of business and monetary factors was found to be significantly negative for MFIs' social efficiency only. Furthermore, this research stresses that investment freedom and financial freedom are statistically positive for financial efficiency, but negative for the social efficiency of MFIs. This study should prove useful for various institutions and have several implications for MFIs, policymakers, investors and researchers to improve the efficiency level of MFIs.
\end{abstract}

Keywords: competition freedom, microfinance institutions, regulatory efficiency, market openness, efficiency JEL Classification: G21, G28

Received: March, 2020

1st Revision: May, 2020

Accepted: May, 2020

\section{INTRODUCTION}

Economic or competition freedom is the fundamental right of a citizen to control labor and property comprised of the dimensions of regulatory efficiency and market openness. The three 
components of business, labor and monetary freedom are used to measure regulatory efficiency. Market openness consists of three measurements: trade, investment and financial freedom. The dimensions of competition freedom affect the economically disadvantaged population to generate incomes, such as by starting a new business along with assuring higher wages and the stable prices of products. When the poor have a higher ability to earn money, they can repay loans as well as have the ability to increase their financial efficiency, which regarding microfinance institutions is their ability to secure full cost recovery without being subsidized (Wijesiri et al., 2017).

Ananya (2016) pointed out the criticism of MFIs for their being ineffective, a critique that the researcher describes as due to their labeling as a concept developed by millennials. Dorfleitner et al. (2017) has described that mission drift would occur if the trade-off between financial performance and the outreached was due to weak social performance. Hence, this study was conducted to investigate the efficiency of MFIs in terms of their financial and social aspects. MFIs in Cambodia, Indonesia, Malaysia, Philippines and Thailand were targeted in this study. In short, the present study focuses on the effects of regulatory efficiency and market openness under the dimensions of competition freedom as well as other potential MFIs' specific and macroeconomic determinants towards the efficiency of microfinance in terms of financial and social factors.

This study seeks to provide an extension of knowledge in competition freedom as well as MFIs. Only a limited number of studies could be found that link both competition freedom and MFIs as well as explore the relationships between these factors. Therefore, the present study attempts to fill this research gap by examining the relationship between competition freedom and MFIs' efficiency. In addition, this research seeks to provide a clearer picture of the operations of MFIs, especially to the public of the selected five countries. Furthermore, the present study also attempts to discover other factors regarding MFIs' specifics and macroeconomics that may contribute to MFIs' efficiency socially and financially. MFIs have been found to be effective in adopting suitable strategies for boosting MFIs' efficiencies and thus deliver the best financial services to the poor. Lastly, government and policymakers may adapt the empirical findings from this study to create better policy and platforms to enhance the efficiency of MFIs.

The structure of the paper is set out as follows: in the next section, the authors provide reviews of the related literature. Section 3 discusses the methods and variables that are employed in the study. The empirical findings are presented in section 4 . The last section of the paper consists of the conclusions along with discussions on policy implications.

\section{THEORETICAL BACKGROUND}

Lebovics et al. (2016) found that Vietnamese MFIs have high financial and social efficiency in their operations. The results of the study also show that there is no relationship between financial and social efficiency, indicating no trade-off. Nevertheless, in a study by Hermes et al. (2018), it was affirmed that the social efficiency of MFIs has a negative correlation with MFIs' efficiency. Interestingly, Louis et al. (2013) show that social efficiency is significantly positive, as well as the finding that it relates to financial efficiency. These are fundamentally different results as compared to previous studies, and they imply that increasing financial efficiency does not appear to trade off with social efficiency, but it does help to increase social efficiency. 
Wijesiri et al. (2017) found that the size of MFIs has a positive effect on efficiency of both social and financial factors. The greater size and capacity of MFIs indicates that they can achieve higher efficiency in both financial and social aspects by possessing more resources such as assets, employees, customers, and credit lines. However, Demirgüneş \& Üçler (2015) showed a negative relationship with profitability and firm size. When a larger bank ceases to enjoy economies of scale, diseconomies of scale lead to high operation costs and an increase in long-term average production cost.

In a paper by Nanayakkara (2017), the age of MFIs negatively influences their performance, i.e. newer MFIs are more efficient than old ones. The reasons are that microfinance is a new industry; hence young MFIs need to learn from the past mistakes made by old MFIs, and they take time to improve their performance gradually. In another study, Wijesiri et al. (2017) investigated the relationship between the age and efficiency of MFIs, determining that older MFIs have higher efficiency in financial performance. Researchers believe that MFIs require a certain period to grow, capture the market and become business specialized in the search for the greatest degree of sustainability.

Results from Imai et al. (2011), revealed a positive relationship between MFIs' ROA and the financial performance of MFIs. ROA represents the main operation of MFIs, including granting loans, monitoring operating activities that generate income, and evaluating profitability based on MFIs' funding structure. This positive relationship implied better ROA of MFIs and a higher efficiency of MFIs. Another study conducted by Abdulai \& Tewari (2016) used the Cobb-Douglas stochastic cost frontier model to investigate the determinants of MFIs' efficiency, with results indicating that ROA has no significant relationship with MFIs' efficiency. These findings suggest that cost efficiency may be attributed to the measurement of profitability in an unadjusted way. However, a study of Palečková (2015) showed that ROA has a negative relationship with efficiency in the Czech banking industry.

Quayes (2012) found that the relationship between debt to equity (DTE) and financial efficiency is negatively correlated, a result suggesting that a higher the total expense ratio will lead to a negative impact on the profitability and financial sustainability of a firm. However, Abrar \& Javaid (2016) argue that DTE ratio has a positive impact on efficiency. This finding indicates that MFIs earn a higher profit while having a higher DTE ratio of MFIs.

Gaganis (2016) investigated the relationship between GDP and performance of MFIs, with results showing a positive relationship between GDP and MFIs' overall performance. This finding might be seen as implying that good economic performance can boost the productivity of MFIs. On the other hand, Donou-Adonsou \& Sylwester (2017) found a negative correlation between real GDP and microfinance growth, a result that seems to indicate that the higher the real GDP functions in a country, the lower the microfinance growth in the country is.

Gaganis (2016) examined the relationship between inflation and the efficiency of MFIs and found no significant relationship, i.e. a higher or a lower inflation rate does not affect the efficiency of MFIs. Sufian \& Zulkhibri (2015) revealed that inflation has a positive relationship with bank profitability; further results showed that inflation reduces the real value of non-performing loans (NPL), therefore it is preferable by banks. 
As for monetary freedom, this study also showed a negative relationship with bank efficiency in Malaysia. These results indicate that higher monetary freedom hinders the efficiency of banking in Malaysia (Sufian \& Zulkhibri, 2015). However, De Haan \& Sturm (2000) showed that monetary freedom has a positive relationship with economic growth.

Slightly different from De Haan \& Sturm, the research of Sufian \& Zulkhibri (2015) determined that business freedom has a negative relationship with bank efficiency in Malaysia. This finding indicates that higher business freedom decreases the barriers for competitors to enter banking sectors. An increasing competition in the banking sector reduces the efficiency of banks. In contrast, an earlier study by Sufian \& Habibullah (2014) showed a positive relationship between business freedom and profitability of banks. This contradictory result explained that higher business freedom assists entrepreneurs in starting a business, which directly increases job creation. Consequently, the profitability of banks is also increased.

Chortareas et al. (2013) revealed that there is a clear positive relationship between financial freedom and bank efficiency. The result suggested that operating and efficiencies of the financial intermediaries can be increased by creating more competitive policies when this takes place in a less restricted environment. Therefore, when a bank has lesser financial freedom, the firm may face inefficiency, and it cannot allocate resources most efficiently. However, this result is contradicted by other researchers who found a negative relationship between financial freedom and bank efficiency in Sub-Saharan Africa (Sarpong-Kumankoma et al., 2017). This study suggested that a lower control of financial freedom by the government leads to lower bank efficiency. In contrast to Sarpong-Kumankoma, a study by Sufian \& Habibullah (2014) declared that there is no relationship between financial freedom and bank profitability. Furthermore, Al-gasaymeh (2018) revealed that there is a significant negative relationship between investment freedom and country efficiency, a result indicating that more freedom in investment reduces the costs of banking on a large scale.

\section{RESEARCH OBJECTIVE, METHODOLOGY AND DATA}

The main purpose of this paper is to examine the effects of two dimensions of competition freedom, namely regulatory efficiency and market openness on the efficiency of microfinance institutions (MFIs) in both social and financial aspects.

In this study, the data consisted of 167 MFIs in Cambodia, Indonesia, Malaysia, Philippines and Thailand had been collected from the years 2011 to 2017. The number of observations collected during the period was 1169 (167 MFIs x 7 years). The main components of data collected include MFIs' determinants, macroeconomic determinants and economic or competition freedom indexes. For MFIs' determinants, the data were obtained from the Microfinance Information Exchange (MIX) Market, a global, web-based microfinance information platform that compiles both financial and social performance information for more than 1900 MFIs all over the world. Macroeconomic determinants data were collected from the International Monetary Fund (IMF) - an organization that provides macroeconomic and financial related data. Lastly, the data related to competition freedom indexes were obtained from the Heritage Foundation. Their main focus is to improve principles of free enterprise, limited government and individual freedom. 


\subsection{Data Envelopment Analysis (DEA)}

To measure input-oriented technical efficiency (TE) of MFIs decomposed of two components, namely pure technical efficiency (PTE) and scale efficiency (SCE), the non-parametric Data Envelopment Analysis (DEA) method was employed with the variable returns to scale (VRTS) model in this study. Besides, the other technical efficiency decompositions, namely pure technical and scale efficiencies, were also investigated at this stage to identify the factors that may influence the MFIs' technical efficiency. There are numerous researchers, Kamarudin et al. (2014), Hussain et al., (2018), Grmanová \& Ivanová (2018); Liu (2019), who employed this method has been to measure the efficiency of the financial institutions. Although this method widely used by the researchers to examine the efficiency level, it also has several limitations such as a difficuly to perform a statistical test with the results, no suggested improvement provided, ignoring the effect of exogenous variables and statistical errors. Nevertheless, DEA also provides several advantages like 1) allows ranking amongst the sample units 2) helps to compare the production performance of each unit 3) does not require a specific functional form to be imposed on the data when identifying and determining the efficient frontier, error and inefficiency structures 4) allows for an arbitrary selection of inputs and outputs 5) suits with a small sample.

\subsection{The Variable Returns to Scale Model}

This study employed the DEA under the model of VRTS by adding the convexity constraint in the constant return to scale (CRTS) model: $N 1$ ' $\lambda=1$ (Coelli et al., 1998):

$\min _{\theta, \lambda} \theta$,

subject to

$-y_{i}+Y \lambda \geq 0$,

$\theta x_{i}-X \lambda \geq 0$,

$N 1^{\prime} \lambda=1$

$\lambda \geq 0$

Where :

$N 1$ is a $N \times 1$ vector of ones.

This approach forms a convex hull of intersecting planes, which envelope the data points more tightly than the CRTS conical hull, and thus provides TE scores that are greater than or equal to those obtained using the CRTS model.

The list of input and output variables used to measure MFIs' social efficiency and financial efficiency are modelled in Table 1. Although several studies suggest that the DEA method requires the selection of inputs and outputs to be an arbitrary issue (Sufian \& Kamarudin, 2014), all the inputs and outputs in this study are based on the intermediation approach and most suitable to measure the efficiency of MFIs suggested by the latest study Zainal et al. (2019) 
Tab. 1- Input and output variables for social and financial efficiency. Source: Zainal et al. (2019); Sufian \& Kamarudin (2014)

\begin{tabular}{|l|l|l|l|}
\hline Variable & Variable name & Description & Efficiency \\
\hline \multirow{3}{*}{ Input } & Asset & $\begin{array}{l}\text { Total asset available to MFI from capi- } \\
\text { tal or borrowings }\end{array}$ & SE \& FE \\
\cline { 2 - 4 } & Operating expenses & All operating expenses & SE \& FE \\
\cline { 2 - 4 } & Personnel & Staffs' salaries & SE \& FE \\
\hline Output & Average loan balance & $\begin{array}{l}\text { Average loan balance per borrower } \\
\text { over Gross National Income (GNI) } \\
\text { per capita }\end{array}$ & SE \\
\cline { 2 - 5 } & Number of borrowers & Number of active borrowers & SE \\
\cline { 2 - 5 } & Financial revenue & $\begin{array}{l}\text { Total revenue from gross loan portfo- } \\
\text { lio including margin charge for loans }\end{array}$ & FE \\
\hline
\end{tabular}

Note: SE \& FE indicates Social Efficiency and Financial Efficiency.

\subsection{Multiple Panel Regression Analysis}

The ordinary least square (OLS) regression method is employed in the second stage of the regression analysis to examine the relationship between MFIs' efficiency and other potential internal and external determinants (MFIs' specific characteristics, macroeconomic conditions and competition freedom). The regression estimation models based on White (1980) transformation, which is robust to heteroscedasticity and the distribution of the disturbances in the second stage of the regression analysis, involves DEA efficiency scores as the dependent variable.

By using the efficiency scores as the dependent variable, the present study estimates the following baseline regression model:

$$
\begin{gathered}
\text { Efficiency }_{i, t}=\beta_{1} \sum_{n=i}^{4} \text { MFIs Characteristics }{ }_{i, t}+\beta_{2} \sum_{n=i}^{2} \text { Macroeconomics }_{t}+ \\
\beta_{3} \sum_{n=i}^{2} \text { Competition Freedom }+\varepsilon_{i, t}
\end{gathered}
$$

Where Efficiency denotes the social and financial efficiency -- scores derived from the DEA method, MFI Characteristics points a vector of MFIs-specific characteristics (lnTA, LnAGE, LnROA, LnDTE), Macroeconomics (LnGDP, LnCPI) represents a set of macroeconomic variables, Competition Freedom (LnBusiFree, LnMoneFree, LnInvestFree, LnFinaFree) denotes a set of competition freedom variables, $\varepsilon$ means the error term, and subscripts -- $i$ and $t$ represent individual MFIs and period, respectively.

For the second stage, the researchers applied the multiple panel regression analysis framework based on the OLS. Breusch and Pagan Lagrangian Multiplier Chi-Square (BPLM $\chi^{2}$ ) test is used to test the suitability to use pull or panel. Furthermore, this study also applied an additional estimation method (panel) known as Generalized Least Square (GLS), a generalized method of the moment. Therefore, the GLS method comprises two estimation methods, which are Fixed Effect Model (FEM) and Random Effect Model (REM). This method is used to examine potential determinants of MFIs' efficiency. To identify which model is suitable under the GLS method, the test used under as for FE and RE for this study is the Hausman test. 


\section{RESULTS AND DISCUSSION}

\subsection{Social and Financial Efficiencies of MFIs}

Table 2 illustrates the mean scores of MFIs in terms of FE and SE from five selected countries.

Each table has a total of 8 panels, e. g. Panel A to Panel G represent the years from 2011 to 2017, and Panel H denotes all the years. The maximum efficiency value of 1 means that a MFI is fully efficient or fully utilising the input to produce the maximum output. However, if the value is lower than 1, an MFI is considered relatively inefficient. Therefore, the values of PTE, SCE and TE for FE and SE of MFIs' scores are bounded within the 0 and 1 range.

Over the years (Panels A to G), the mean trend of PTE for MFIs' financial efficiency fluctuates, wherein the year(s) 2011, it was 76.7\%, 2012 (80.1\%), 2013 (79.8\%), 2014 (81.7\%), 2015 (81.2\%), 2016 (82\%) and 2017 (80.5\%), respectively. The lowest mean score of PTE was in the year 2011, and the highest one in the year 2016.

On the other hand, MFIs' social efficiency, results showed that during the years 2011 to 2014 (Panels A to D), the mean of PTE of MFIs increased from $41.6 \%$ to $44.7 \%$, respectively. However, during 2015, the score decreased to $37 \%$ and it rose again to the maximum level of $46 \%$ in 2016. Nevertheless, it was slightly reduced in the year 2017 (45.2\%). The trend shows that the lowest score occurred in 2011 and the highest one in 2016.

In general, for all years (Panel $\mathrm{H}$ ), the financial efficiency of MFIs was recorded as average $73.6 \%$ with an average input waste of $26.4 \%$. The mean of SCE for all years recorded $91.9 \%$, which that means that SCE contributed only which $8.1 \%$, and the rest was contributed by PTE, which was $19.7 \%$. The result suggested that PTE is the main reason for inefficiency in financial efficiency. The outcome also suggested that MFIs could reduce $26.4 \%$ of the current inputs to reach the current output.

On the other hand, the mean PTE in social efficiency for all MFIs in all years (Panel H) recorded an average of $43 \%$, along with TE $32.4 \%$ and SCE $74.4 \%$. The result suggested that the overall average of MFIs' efficiency level of only $32.4 \%$ is efficient and remaining $67.6 \%$ inefficient. The result further suggested that the average PTE that represents pure managerial factors contribute the highest to the inefficiency of social efficiency of MFIs as PTE is only efficient at $43 \%$ with $57 \%$ input waste while SCE is efficient at $74.4 \%$ with only $25.6 \%$ input waste. Thus, the result of the present study implied that MFIs could reduce an average of $67.6 \%$ of their input to produce the same amount of current outputs. In other words, if MFIs are fully efficient, only $32.4 \%$ of current input will be required to achieve the same amount of outputs that current MFIs produce. To sum up, the results suggested that during the study period, the main reason for MFIs' inefficiency is due to being managerially inefficient. The management of MFIs failed to utilize their resources fully and led to the waste of resources although MFIs had been operating on a relatively optimal scale. 
Tab. 2 - MFIs' FE and SE score from 5 countries. Source: own research

\begin{tabular}{|c|c|c|c|c|c|c|c|c|}
\hline Efficiency & Mean & Min & Max & $\begin{array}{l}\text { Std. } \\
\text { Dev. }\end{array}$ & & & & \\
\hline & $\mathrm{FE}$ & SE & FE & SE & $\mathrm{FE}$ & $\mathrm{SE}$ & $\mathrm{FE}$ & $\mathrm{SE}$ \\
\hline \multicolumn{9}{|c|}{ Panel A: 2011} \\
\hline PTE & 0.767 & 0.416 & 0.046 & 0.045 & 1.000 & 1.000 & 0.187 & 0.291 \\
\hline SCE & 0.911 & 0.837 & 0.296 & 0.083 & 1.000 & 1.000 & 0.124 & 0.184 \\
\hline TE & 0.699 & 0.342 & 0.029 & 0.032 & 1.000 & 1.000 & 0.186 & 0.254 \\
\hline \multicolumn{9}{|c|}{ Panel B: 2012} \\
\hline PTE & 0.801 & 0.430 & 0.001 & 0.020 & 1.000 & 1.000 & 0.145 & 0.294 \\
\hline SCE & 0.935 & 0.804 & 0.001 & 0.069 & 1.000 & 1.000 & 0.127 & 0.195 \\
\hline TE & 0.750 & 0.343 & 0.001 & 0.015 & 1.000 & 1.000 & 0.154 & 0.259 \\
\hline \multicolumn{9}{|c|}{ Panel C: 2013} \\
\hline PTE & 0.798 & 0.438 & 0.346 & 0.047 & 1.000 & 1.000 & 0.145 & 0.289 \\
\hline SCE & 0.944 & 0.781 & 0.296 & 0.067 & 1.000 & 1.000 & 0.104 & 0.199 \\
\hline TE & 0.752 & 0.340 & 0.271 & 0.030 & 1.000 & 1.000 & 0.157 & 0.251 \\
\hline \multicolumn{9}{|c|}{ Panel D: 2014} \\
\hline PTE & 0.817 & 0.447 & 0.498 & 0.052 & 1.000 & 1.000 & 0.136 & 0.293 \\
\hline SCE & 0.922 & 0.765 & 0.313 & 0.060 & 1.000 & 1.000 & 0.102 & 0.202 \\
\hline TE & 0.750 & 0.338 & 0.313 & 0.034 & 1.000 & 1.000 & 0.137 & 0.247 \\
\hline \multicolumn{9}{|c|}{ Panel E: 2015} \\
\hline PTE & 0.812 & 0.370 & 0.318 & 0.001 & 1.000 & 1.000 & 0.146 & 0.330 \\
\hline SCE & 0.906 & 0.552 & 0.289 & 0.003 & 1.000 & 1.000 & 0.108 & 0.370 \\
\hline TE & 0.731 & 0.257 & 0.289 & 0.001 & 1.000 & 1.000 & 0.141 & 0.273 \\
\hline \multicolumn{9}{|c|}{ Panel F: 2016} \\
\hline PTE & 0.820 & 0.460 & 0.442 & 0.043 & 1.000 & 1.000 & 0.153 & 0.301 \\
\hline SCE & 0.908 & 0.737 & 0.304 & 0.050 & 1.000 & 1.000 & 0.104 & 0.232 \\
\hline TE & 0.742 & 0.325 & 0.304 & 0.029 & 1.000 & 1.000 & 0.156 & 0.240 \\
\hline \multicolumn{9}{|c|}{ Panel G: 2017} \\
\hline PTE & 0.805 & 0.452 & 0.348 & 0.066 & 1.000 & 1.000 & 0.141 & 0.294 \\
\hline SCE & 0.908 & 0.734 & 0.330 & 0.089 & 1.000 & 1.000 & 0.115 & 0.241 \\
\hline TE & 0.725 & 0.321 & 0.33 & 0.041 & 1.000 & 1.000 & 0.133 & 0.240 \\
\hline \multicolumn{9}{|c|}{ Panel H: All Years } \\
\hline PTE & 0.803 & 0.430 & 0.286 & 0.039 & 1.000 & 1.000 & 0.150 & 0.299 \\
\hline SCE & 0.919 & 0.744 & 0.261 & 0.060 & 1.000 & 1.000 & 0.112 & 0.232 \\
\hline $\mathrm{TE}$ & 0.736 & 0.324 & 0.220 & 0.026 & 1.000 & 1.000 & 0.152 & 0.252 \\
\hline
\end{tabular}

Note: TE, PTE, SCE, FE and SE indicates Technical Efficiency, Pure Technical Efficiency, Scale Efficiency, Financial Efficiency and Scale Efficiency 


\subsection{Robustness Test}

After analyzing the efficiency of MFIs in both financial and social aspects, the following interesting issue is whether the gap between TE, PTE and SCE of MFIs is statistically significant. Sufian \& Kamarudin (2015) suggested obtaining more robust results; hence this study performed a series of robustness checks, including parametric (t-test) and non-parametric (Mann-Whitney and Kruskal-Wallis). Table 3 shows the robustness tests for overall MFIs in Cambodia, Indonesia, Malaysia, Philippines and Thailand.

Table 3 presents the results on both parametric and non-parametric tests that suggest the overall financial efficiency of MFIs that tend to have a higher mean PTE level than social efficiency $(0.803>0.430)$ and significantly different at $1 \%$. A similar result was also found; financial efficiency tends to have higher mean SCE $(0.919>0.744)$ and TE $(0.735>0.324)$ levels when compared to social efficiency and significantly different at $1 \%$. The result from the parametric t-test is further confirmed by the non-parametric Mann-Whitney (Wilcoxon) and Kruskal-Wallis test.

Overall, all countries show the financial efficiency levels, which are higher than social efficiency and significant at 1\% under the PTE (except for Thailand being insignificant). This finding indicates that all the MFIs from the selected countries are financially stable to provide a continuous financial service to poor people. Thus, it can reduce poverty since it is a crucial role of the MFIs. Unlike banking institutions, the term financial sustainability denotes to the ability of MFIs to generate their income, and no longer depends on subsidies to operate the business. The subsidies from the government are unable to ensure the financial sustainability of MFIs since the fund can be reduced or taken away following the country economic condition. Generally, financial efficiency in MFIs is not restricted to the profitability, but rather focuses on the MFI ability to operate in the long term without having a risk of bankruptcy.

However, regarding the overall efficiency (TE), only MFIs in Thailand show the social efficiency levels that are higher than financial efficiency, and both parametric and non-parametric tests proved the results are significant at $1 \%$ levels. This result indicates that the MFIs in Thailand are more socially efficient, which suggests the depth of outreach and the breadth of outreach. The depth of the outreach is based on the coverage of MFIs that have included the high relative poverty levels of borrowers while the breadth of the outreach is being served as for the number of clients with the financial services. Moreover, MFIs should retain their social efficiency goal because they need to provide financial assistance to indigent clients to alleviate poverty. The economic growth of a country may decline due to the poor, and it does not have the opportunity to operate a small business and grant the higher income. This is because they lack collateral for their loan application, do not qualify with a low-income background and have an increased risk of loan default. Therefore, the social role of MFIs is essential to eradicate poverty by aligning to the MFIs' financial goals (Zainal et al., 2019).

As a result, this study may conclude that the MFIs in Cambodia, Indonesia, Malaysia and Philippines are efficient as for the financial efficiency. At the same time, the MFIs in Thailand are more efficient as for social efficiency in the overall efficiency concept. 
Tab. 3 - Robustness tests for the MFIs' FE and SE score 2011-2017. Source: own research

\begin{tabular}{|c|c|c|c|c|c|c|c|}
\hline \multirow{4}{*}{ Country } & \multirow{4}{*}{$\begin{array}{l}\text { Test } \\
\text { statistic }\end{array}$} & \multirow{2}{*}{\multicolumn{2}{|c|}{$\begin{array}{l}\text { Parametric test } \\
\text { t-test }\end{array}$}} & \multicolumn{4}{|c|}{ Non-parametric test } \\
\hline & & & & \multicolumn{2}{|c|}{ Mann-Whitney test } & \multicolumn{2}{|c|}{ Kruskal-Wallis test } \\
\hline & & \multicolumn{2}{|c|}{$t(\operatorname{Prb}>t)$} & \multicolumn{2}{|c|}{$z(\operatorname{Prb}>z)$} & \multicolumn{2}{|c|}{$x^{2}\left(\operatorname{Prb}>x^{2}\right)$} \\
\hline & & Mean & $\mathrm{t}$ & $\begin{array}{l}\text { Mean } \\
\text { rank }\end{array}$ & $z$ & $\begin{array}{l}\text { Mean } \\
\text { rank }\end{array}$ & $x^{2}$ \\
\hline \multicolumn{8}{|l|}{ PTE } \\
\hline \multirow{2}{*}{ All } & FE & 0.803 & $38.053 \mathrm{a}$ & 1564.12 & $-27.728 a$ & 1564.12 & $768.845 a$ \\
\hline & SE & 0.43 & & 788.883 & & 788.883 & \\
\hline \multirow{2}{*}{ Cambodia } & FE & 0.742 & $5.064 \mathrm{a}$ & 151.628 & $-3.858 \mathrm{a}$ & 151.628 & $14.887 \mathrm{a}$ \\
\hline & SE & 0.584 & & 115.372 & & 115.372 & \\
\hline \multirow{2}{*}{ Indonesia } & $\mathrm{FE}$ & 0.832 & $31.146 a$ & 569.816 & $-18.850 \mathrm{a}$ & 569.816 & $355.314 \mathrm{a}$ \\
\hline & SE & 0.321 & & 257.184 & & 257.184 & \\
\hline \multirow{2}{*}{ Malaysia } & $\mathrm{FE}$ & 0.716 & $7.634 \mathrm{a}$ & 20.786 & $-4.043 a$ & 20.786 & $16.349 \mathrm{a}$ \\
\hline & SE & 0.193 & & 8.214 & & 8.214 & \\
\hline \multirow{2}{*}{ Philippines } & $\mathrm{FE}$ & 0.795 & $26.916 \mathrm{a}$ & 809.518 & $-20.693 a$ & 809.518 & $428.200 \mathrm{a}$ \\
\hline & SE & 0.465 & & 395.482 & & 395.482 & \\
\hline \multirow{2}{*}{ Thailand } & FE & 0.955 & 0.975 & 15.821 & -0.919 & 15.821 & 0.844 \\
\hline & SE & 0.927 & & 13.179 & & 13.179 & \\
\hline \multicolumn{8}{|l|}{ SCE } \\
\hline \multirow{2}{*}{ All } & $\mathrm{FE}$ & 0.919 & $21.602 \mathrm{a}$ & 1443.4 & $-19.066 a$ & 1443.4 & $363.513 \mathrm{a}$ \\
\hline & SE & 0.744 & & 909.605 & & 909.605 & \\
\hline \multirow{2}{*}{ Cambodia } & $\mathrm{FE}$ & 0.823 & $8.394 \mathrm{a}$ & 163.492 & $-6.359 a$ & 163.492 & $40.441 \mathrm{a}$ \\
\hline & SE & 0.582 & & 103.508 & & 103.508 & \\
\hline \multirow{2}{*}{ Indonesia } & FE & 0.925 & $6.359 \mathrm{a}$ & 549.299 & $-16.361 \mathrm{a}$ & 549.299 & $267.695 a$ \\
\hline & SE & 0.636 & & 277.701 & & 277.701 & \\
\hline \multirow{2}{*}{ Malaysia } & FE & 0.73 & $3.290 \mathrm{a}$ & 19.214 & $-3.033 a$ & 19.214 & $9.196 \mathrm{a}$ \\
\hline & SE & 0.549 & & 9.786 & & 9.786 & \\
\hline \multirow{2}{*}{ Philippines } & $\mathrm{FE}$ & 0.949 & $14.941 \mathrm{a}$ & 728.56 & $-12.586 a$ & 728.56 & $158.409 \mathrm{a}$ \\
\hline & SE & 0.854 & & 476.44 & & 476.44 & \\
\hline \multirow{2}{*}{ Thailand } & $\mathrm{FE}$ & 0.585 & $-5.015 \mathrm{a}$ & 8 & $-4.236 a$ & 8 & $17.944 \mathrm{a}$ \\
\hline & SE & 0.98 & & 21 & & 21 & \\
\hline \multicolumn{8}{|l|}{ TE } \\
\hline \multirow{2}{*}{ All } & $\mathrm{FE}$ & 0.735 & $47.720 \mathrm{a}$ & 1645.88 & $-33.525 a$ & 1645.88 & $1123.898 \mathrm{a}$ \\
\hline & SE & 0.324 & & 707.117 & & 707.117 & \\
\hline \multirow{2}{*}{ Cambodia } & FE & 0.602 & $11.050 \mathrm{a}$ & 179.15 & $-9.678 a$ & 179.15 & $93.669 \mathrm{a}$ \\
\hline & SE & 0.324 & & 87.85 & & 87.85 & \\
\hline
\end{tabular}




\begin{tabular}{|l|l|l|l|l|l|l|l|}
\hline \multirow{2}{*}{ Indonesia } & FE & 0.769 & $40.176 \mathrm{a}$ & 593.247 & $-21.655 \mathrm{a}$ & 593.247 & $468.928 \mathrm{a}$ \\
\cline { 2 - 8 } & SE & 0.218 & & 233.753 & & 233.753 & \\
\hline \multirow{2}{*}{ Malaysia } & $\mathrm{FE}$ & 0.504 & $9.429 \mathrm{a}$ & 21.5 & $-4.541 \mathrm{a}$ & 21.5 & $20.620 \mathrm{a}$ \\
\cline { 2 - 8 } & SE & 0.09 & & 7.5 & & 7.5 & \\
\hline Philippines & $\mathrm{FE}$ & 0.752 & $33.974 \mathrm{a}$ & 848.023 & $-24.506 \mathrm{a}$ & 848.023 & $600.521 \mathrm{a}$ \\
\cline { 2 - 8 } & SE & 0.388 & & 356.977 & & 356.977 & \\
\hline \multirow{2}{*}{ Thailand } & $\mathrm{FE}$ & 0.545 & $-5.029 \mathrm{a}$ & 8 & $-4.236 \mathrm{a}$ & 8 & $17.944 \mathrm{a}$ \\
\cline { 2 - 8 } & SE & 0.91 & & 21 & & 21 & \\
\hline
\end{tabular}

Note: a, indicates significance at $1 \%$ levels.

\subsection{Determinants of MFIs Efficiency}

In Tables 4 to 9, all models have been constructed and analyzed for both financial and social efficiency. Model 1 has been set as a baseline regression model that only includes MFIs' specific determinant variables, which are the size of MFIs (lnTA), total years of operation of MFIs (lnAGE). The profitability of MFIs is measured by the ratio of profit divided by the total asset (lnROA). The leverage level of MFIs is measured by the ratio of total debts divided by total equity (lnDTE). In Model 2, macroeconomic variables, namely economic growth (lnGDP) and consumer price index (lnCPI) are included along with the variables in Model 1, which are MFIs' specific determinant variables (Tables 4 and 7). The following regression model represents two pillars of the competition freedom which includes regulatory efficiency and market openness. Referring to Tables 5 and 8 , regulatory efficiency is measured by business freedom (lnBusiFree) in Model 1, and monetary freedom (lnMoneFree) in Model 2. In Tables 6 and 9, the market openness in competition freedom is measured by investment freedom (lnInvestFree) in Model 1 and financial freedom (lnFinaFree) in Model 2.

In the preliminary stage, all models have shown a significant level of $5 \%$ in a p-value of the BPLM $\chi 2$ test. This result shows that instead of pooled data OLS, panel data GLS is more suitable for all models in both financial and social efficiency. Furthermore, as for financial efficiency regression models in Tables 4, 5 and 6, all models apply FEM, except for Model 1 in Table 4. On the other hand, regarding social efficiency regression models in Tables 7, 8 and 9 respectively, all models suitable to employ FEM as the all of the significant levels for the Hausman test (x2) are at $1 \%$ level.

On one hand, Tables 4, 5 and 6 show that total assets (lnTA) have a significant positive relationship with MFIs financial efficiency of MFIs in all models (except for Table 5 Model 2) that suggest that the larger (smaller) size of MFIs tends to exhibit higher (lower) levels of financial efficiency. The bigger size of MFIs tends to have higher opportunities in economies of scale, and the results support market power premises. The result is consistent with findings of Wijesiri et al. (2017) and Quayes (2012). On the other hand, lnTA has 1\% and, therefore, has a significant negative relationship with social efficiency for Table 7 (Models 2), Table 8 (Model 1) and Table 9 (Model 2). This result explains that when large MFIs enjoy the economies of scale, diseconomies of scale lead to higher operating costs and long-term average production cost (Demirgüneş \& Üçler, 2015). 
Besides, the coefficient of $\ln$ AGE has shown a significantly negative relationship with both financial and social MFIs' efficiency from Tables 4 to 9 (except for Model 1 in Tables 4 and 7). The result implies that the younger (older) MFIs tend to have higher (lower) financial and social efficiency. The study result also provides support to the argument that young MFIs can learn from past mistakes made by old MFIs and improve their performance in a period of time (Nanayakkara, 2017). Moreover, another argument supports the fact that young MFIs can adopt new technologies and interventions from the oldest to latest technologies. Hence younger MFIs have higher efficiency in operations and lead to higher profit (Abdelkader \& Mansouri, 2019). Therefore, the older MFIs tend to operate in lower efficiency when compared to younger MFIs.

The profitability of MFIs (lnROA) has a positive and significant effect at $1 \%$ and $5 \%$ levels to social efficiency only (Tables 7, 8 and 9 respectively) in all models. This result implies that the better ROA of MFIs, the higher efficiency of MFIs. The evidence is further supported by Mia \& Soltane (2016). Their study state that better ROA can boost MFIs' productivity. Therefore, MFIs should target and explore different types of financially viable projects to increase the ROA of MFIs. The findings also suggest that the leverage (lnDTE) is related significantly negative for MFIs' financial efficiency only in Table 4 (Model 1). The result shows that a higher total expense ratio leads to a negative impact on the profitability and financial sustainability of a firm. This finding indicates that the more debt a firm employs in financing its operations the inferior financial performance it registers.

Next, both efficiencies have shown a significant positive relationship with lnGDP (except for Table 4 Model 2 and Table 5 Model 2). This can support the argument that good economic performance can increase the productivity of MFIs and the resources are used efficiently. Besides, the result also implies that when GDP rises, the income of citizens, including borrowers, also improves. An increment of income by borrowers leads to being financially more stable and enable them to pay the loan continuously. The stability of loan repayment indicates high financial efficiency of MFIs, and MFIs can use the returned money to lend to more people. Hence, it also leads to higher social efficiency.

The following variables, inflation (lnCPI), show a positive sign being statistically significant in financial and social efficiencies (Table 6 Model 1 and Table 8 both models). The inflation reduces the real values of non-performing loans (NPL), therefore, it is preferable by MFIs. MFIs may obtain higher income since the number of borrowers increases even though the interest rate is higher because the consumers assume there will be much higher inflation in the future, which will lead to a further rise in interest rates.

\subsection{Does Competition Freedom Foster MFIs' Efficiency?}

In regard to the competition freedom, two dimensions of regulatory efficiency and market openness have been analyzed in Tables 5, 6, 8 and 9. The result shows that the coefficient of $\ln$ BusiFree is negative and significant at 5\% level with social efficiency (Table 8 Model 1). This finding indicates that higher business freedom decreases the barriers of competitors to enter MFIs sector. The greater ability to establish and operate a new business may increase the MFIs entry barriers. Therefore, it may increase the level of competition and dampen the efficiency level of MFIs. An increasing competition in MFIs' sector reduces the MFIs social efficiency. 
The measurement of regulatory efficiency, which is monetary freedom (lnMoneFree), shows a negative and significant impact at 1\% level with MFIs' social efficiency (Table 8 Model 2). This outcome of the study indicates that higher (lower) government interventions in the market tends to enhance (decrease) social efficiency. The intervention from the government requires ensuring the reliability and stability of monetary policy that is important to MFIs for generating wealth, and increasing their income to assist a higher number of poor people. This finding is supported by another study (Sufian and Habibullah, 2014) which reveals that there are advantages of government interventions contention as the monetary freedom has a negative relationship with banks profitability. A constant and reliable monetary policy plays an essential role for organizations and societies when making decisions about investment, savings and other long-term plans.

On one hand, this research identifies that the investment freedom (lnInvestFree) shows a positive relationship with financial efficiency which indicates the higher investment freedom, which leads to a higher MFIs' financial efficiency (Table 6 Model 1). This activity allows the MFIs to be independent of choosing the excellent investment portfolio without any intervention from the authority, and this may enhance their skills for the future mainly when making a strategy on how to maximize their return form investment. On the other hand, investment freedom appears significantly negative at $5 \%$ level as for social efficiency (Table 9 Model 1). The result suggests that the more (less) freedom in investment ensures the greater (smaller) cost for marketing, hence lower (higher) social efficiency. The result also suggests that when investment freedom increases, investors have more option to invest based on their preferences, thus, more investment option appears and tends to decrease the potential investor for MFIs. Besides, MFIs are likely to reduce efforts to developed relationships with the borrowers in competitive markets because the relationships may not sustain and that may lead to less reusability and information value. The borrower may do a survey in the market to identify which MFIs can offer a better interest rate. Therefore, to retain the existing client and to attract more new customers, this activity involves MFIs with a high cost for investing in the high-tech latest technology and marketing efforts. A similar result can be seen in other studies conducted by Al-gasaymeh (2018).

With regard to the relationship between financial freedom (lnFinaFree) and financial efficien$\mathrm{cy}$, the result shows that the coefficient for financial freedom has a positive sign for financial efficiency only (Table 6 Model 2). The result also supports the argument that a less restricted environment can create more competitive policies and then help in increasing efficiencies of MFIs. In other words, if the countries have low financial freedom, MFIs in those countries cannot allocate resources in the most efficient way, hence facing inefficiency. The same result can also be seen in the study of Chortareas et al. (2013); Sufian \& Zulkhibri (2015). However, this financial freedom is significantly negative as for social efficiency (Table 9 Model 2). The result reveals that fewer subsidies by the government lead to a lower MFIs' social efficiency. MFIs from these sample countries still require an intervention by the government when granting them additional funding to support the social activities. 
Tab. 4 - Regression result of the MFIs' FE in all countries without the impact of competition freedom. Source: own research

\begin{tabular}{|c|c|c|c|c|c|c|}
\hline \multirow[t]{2}{*}{ Variable } & \multicolumn{3}{|l|}{ Model 1} & \multicolumn{3}{|l|}{ Model 2} \\
\hline & POLS & FEM & REM & POLS & FEM & REM \\
\hline \multirow[t]{2}{*}{ Constant } & $-0.299 \mathrm{a}$ & $-0.956 c$ & $-0.414 b$ & $-0.544 a$ & $-1.565 b$ & $-0.800 \mathrm{a}$ \\
\hline & $-(0.090)$ & $-(0.513)$ & $-(0.165)$ & $-(0.157)$ & $-(0.668)$ & $-(0.272)$ \\
\hline \multicolumn{7}{|c|}{ MFI's Specific Determinants } \\
\hline \multirow[t]{2}{*}{ LnTA } & $0.015 \mathrm{a}$ & $0.088 \mathrm{a}$ & $0.022 \mathrm{~b}$ & $0.018 \mathrm{a}$ & $0.078 \mathrm{~b}$ & $0.025 b$ \\
\hline & $-(0.005)$ & $-(0.030)$ & $-(0.010)$ & $-(0.005)$ & $-(0.031)$ & $-(0.010)$ \\
\hline \multirow[t]{2}{*}{ LnAGE } & 0.005 & -0.197 & -0.006 & -0.008 & $-0.275 c$ & -0.021 \\
\hline & $-(0.016)$ & $-(0.139)$ & $-(0.031)$ & $-(0.017)$ & $-(0.148)$ & $-(0.032)$ \\
\hline \multirow[t]{2}{*}{ LnROA } & -0.025 & -0.035 & -0.024 & -0.01 & -0.011 & 0.009 \\
\hline & $-(0.022)$ & $-(0.344)$ & $-(0.040)$ & $-(0.025)$ & $-(0.344)$ & $-(0.044)$ \\
\hline \multirow[t]{2}{*}{ LnDTE } & $-0.051 \mathrm{a}$ & -0.003 & $-0.039 b$ & $-0.050 \mathrm{a}$ & -0.008 & $-0.039 \mathrm{~b}$ \\
\hline & $-(0.011)$ & $-(0.041)$ & $-(0.019)$ & $-(0.011)$ & $-(0.041)$ & $-(0.019)$ \\
\hline \multicolumn{7}{|c|}{ Macroeconomics Determinants } \\
\hline \multirow[t]{2}{*}{ LnGDP } & & & & $0.030 \mathrm{~b}$ & 0.129 & $0.046 \mathrm{c}$ \\
\hline & & & & $-(0.014)$ & $-(0.089)$ & $-(0.026)$ \\
\hline \multirow[t]{2}{*}{ LnCPI } & & & & -0.008 & 0.006 & 0.003 \\
\hline & & & & $-(0.009)$ & $-(0.007)$ & $-(0.007)$ \\
\hline $\mathrm{R}^{2}$ & 0.039 & 0.551 & 0.012 & 0.044 & 0.552 & 0.015 \\
\hline Adj $\mathrm{R}^{2}$ & 0.036 & 0.475 & 0.008 & 0.039 & 0.475 & 0.01 \\
\hline F-statistic & $11.845 \mathrm{a}$ & $7.206 \mathrm{a}$ & $3.468 \mathrm{a}$ & $8.888 \mathrm{a}$ & $7.139 \mathrm{a}$ & $2.897 \mathrm{a}$ \\
\hline BPLM $\chi^{2}$ & \multicolumn{3}{|c|}{$711.080 \mathrm{a}$} & \multicolumn{3}{|l|}{$700.110 \mathrm{a}$} \\
\hline Hausman $\chi^{2}$ & \multicolumn{3}{|l|}{7.669} & \multicolumn{3}{|l|}{$14.081 \mathrm{~b}$} \\
\hline Model Used & \multicolumn{3}{|l|}{ REM } & \multicolumn{3}{|l|}{ FEM } \\
\hline No. of Obs. & 1169 & 1169 & 1169 & 1169 & 1169 & 1169 \\
\hline
\end{tabular}

Note: $a, b, c$ indicate significance at $1 \%, 5 \%$ and $10 \%$ levels respectively.

Figures in parentheses () are standard errors.

Tab. 5 - Regression result of the MFIs' FE in all countries with the impact of competition freedom on business and monetary freedom components. Source: own research

\begin{tabular}{|l|l|l|l|l|l|l|}
\hline \multirow{2}{*}{ Variable } & Model 1 & REM & REM & POLS & FEM & REM \\
\cline { 2 - 7 } & POLS & FEM 2 & -1.762 & -0.688 & -0.99 \\
\hline Constant & $-0.833 \mathrm{a}$ & $-1.201 \mathrm{c}$ & $-0.681 \mathrm{c}$ & -1.762 & $-(1.712)$ \\
\hline & $-(0.313)$ & $-(0.704)$ & $-(0.352)$ & $-(1.927)$ & $-(1.818)$ & \\
\hline MFI's Specific Determinant \\
\hline LnTA & $0.019 \mathrm{a}$ & $0.062 \mathrm{c}$ & $0.025 \mathrm{~b}$ & $0.018 \mathrm{a}$ & 0.077 & $0.025 \mathrm{~b}$ \\
\hline
\end{tabular}




\begin{tabular}{|c|c|c|c|c|c|c|}
\hline & $-(0.005)$ & $-(0.032)$ & $-(0.010)$ & $-(0.004)$ & $-(0.057)$ & $-(0.010)$ \\
\hline \multirow[t]{2}{*}{ LnAGE } & -0.008 & $-0.404 b$ & -0.022 & -0.01 & $-0.279 b$ & -0.021 \\
\hline & $-(0.017)$ & $-(0.168)$ & $-(0.032)$ & $-(0.011)$ & $-(0.110)$ & $-(0.032)$ \\
\hline \multirow{2}{*}{ LnROA } & -0.011 & 0.025 & 0.01 & -0.018 & -0.002 & 0.008 \\
\hline & $-(0.025)$ & $-(0.345)$ & $-(0.044)$ & $-(0.021)$ & $-(0.491)$ & $-(0.046)$ \\
\hline \multirow[t]{2}{*}{ LnDTE } & $-0.062 \mathrm{a}$ & -0.007 & $-0.035 c$ & $-0.050 \mathrm{a}$ & -0.009 & $-0.039 \mathrm{~b}$ \\
\hline & $-(0.015)$ & $-(0.041)$ & $-(0.021)$ & $-(0.013)$ & $-(0.016)$ & $-(0.019)$ \\
\hline \multicolumn{7}{|c|}{ Macroeconomics Determinants } \\
\hline \multirow[t]{2}{*}{ LnGDP } & $0.035 \mathrm{~b}$ & $0.228 \mathrm{~b}$ & $0.046 \mathrm{c}$ & $0.032 \mathrm{a}$ & 0.151 & $0.046 \mathrm{c}$ \\
\hline & $-(0.015)$ & $-(0.108)$ & $-(0.026)$ & $-(0.012)$ & $-(0.111)$ & $-(0.026)$ \\
\hline \multirow[t]{2}{*}{ LnCPI } & -0.007 & 0.006 & 0.002 & $-0.006 c$ & 0.005 & 0.003 \\
\hline & $-(0.009)$ & $-(0.007)$ & $-(0.007)$ & $-(0.004)$ & $-(0.003)$ & $-(0.007)$ \\
\hline \multicolumn{7}{|c|}{ Competition Freedom Determinants } \\
\hline \multirow[t]{2}{*}{ LnBusiFree } & 0.072 & -0.126 & -0.03 & & & \\
\hline & $-(0.068)$ & $-(0.077)$ & $-(0.057)$ & & & \\
\hline \multirow[t]{2}{*}{ LnMoneFree } & & & & 0.28 & -0.234 & 0.045 \\
\hline & & & & $-(0.440)$ & $-(0.521)$ & $-(0.396)$ \\
\hline $\mathrm{R}^{2}$ & 0.045 & 0.553 & 0.015 & 0.044 & 0.552 & 0.015 \\
\hline Adj $\mathrm{R}^{2}$ & 0.039 & 0.476 & 0.009 & 0.038 & 0.474 & 0.009 \\
\hline F-statistic & $7.780 \mathrm{a}$ & $7.126 \mathrm{a}$ & $2.515 \mathrm{~b}$ & $7.669 \mathrm{a}$ & $7.094 \mathrm{a}$ & $2.486 \mathrm{~b}$ \\
\hline BPLM $\chi^{2}$ & \multicolumn{3}{|l|}{$692.170 \mathrm{a}$} & \multicolumn{3}{|c|}{$699.300 \mathrm{a}$} \\
\hline Hausman $\chi^{2}$ & \multicolumn{3}{|l|}{$16.890 \mathrm{~b}$} & \multicolumn{3}{|l|}{$15.563 b$} \\
\hline Model Used & \multicolumn{3}{|l|}{ FEM } & \multicolumn{3}{|l|}{ FEM } \\
\hline No. of Obs. & 1169 & 1169 & 1169 & 1169 & 1169 & 1169 \\
\hline
\end{tabular}

Note: a, b, c indicate significance at $1 \%, 5 \%$ and $10 \%$ levels respectively.

Figures in parentheses () are standard errors.

Tab. 6 - Regression result of the MFIs' FE in all countries including components regarding the impact of competition freedom on investment and financial freedom. Source: own research

\begin{tabular}{|l|l|l|l|l|l|l|}
\hline \multirow{2}{*}{ Variable } & \multicolumn{7}{|l|}{ Model 1 } & Model 2 \\
\cline { 2 - 7 } & POLS & FEM & REM & POLS & FEM & REM \\
\hline Constant & $-0.539 \mathrm{a}$ & $-0.687 \mathrm{a}$ & $-1.056 \mathrm{a}$ & $-1.123 \mathrm{a}$ & $-0.609 \mathrm{a}$ & $-0.959 \mathrm{a}$ \\
\hline & $-(0.099)$ & $-(0.152)$ & $-(0.337)$ & $-(0.246)$ & $-(0.146)$ & $-(0.301)$ \\
\hline MFI's Specific Determinants \\
\hline LnTA & $0.021 \mathrm{a}$ & $0.012 \mathrm{c}$ & $0.025 \mathrm{~b}$ & $0.018 \mathrm{a}$ & $0.012 \mathrm{c}$ & $0.025 \mathrm{~b}$ \\
\hline & $-(0.001)$ & $-(0.007)$ & $-(0.010)$ & $-(0.005)$ & $-(0.007)$ & $-(0.010)$ \\
\hline LnAGE & $-0.016 \mathrm{a}$ & $-0.111 \mathrm{a}$ & -0.02 & -0.017 & $-0.079 \mathrm{~b}$ & -0.023 \\
\hline
\end{tabular}




\begin{tabular}{|l|l|l|l|l|l|l|}
\hline & $-(0.006)$ & $-(0.041)$ & $-(0.032)$ & $-(0.017)$ & $-(0.039)$ & $-(0.032)$ \\
\hline LnROA & -0.005 & 0.081 & 0.009 & $-0.049 \mathrm{c}$ & 0.079 & -0.01 \\
\hline & $-(0.009)$ & $-(0.128)$ & $-(0.044)$ & $-(0.028)$ & $-(0.123)$ & $-(0.046)$ \\
\hline LnDTE & $-0.049 \mathrm{a}$ & 0.001 & $-0.040 \mathrm{~b}$ & $-0.049 \mathrm{a}$ & 0.001 & $-0.039 \mathrm{~b}$ \\
\hline & $-(0.003)$ & $-(0.010)$ & $-(0.019)$ & $-(0.011)$ & $-(0.010)$ & $-(0.019)$ \\
\hline Macroeconomics Determinants & 0.009 & $0.061 \mathrm{a}$ & $0.044 \mathrm{c}$ & $0.026 \mathrm{c}$ & $0.039 \mathrm{a}$ & 0.04 \\
\hline LnGDP & 0.009 & $-(0.026)$ & $-(0.014)$ & $-(0.011)$ & $-(0.027)$ \\
\hline & $-(0.010)$ & $-(0.011)$ & 0.006 & 0.005 & 0.001 & 0.006 \\
\hline LnCPI & 0.002 & $0.002 \mathrm{~b}$ & -006 & $-(0.001)$ & $-(0.007)$ \\
\hline \multicolumn{7}{|l|}{} \\
\hline
\end{tabular}

Note: a, b, c indicate significance at $1 \%, 5 \%$ and $10 \%$ levels respectively.

Figures in parentheses () are standard errors.

Tab. 7 - Regression result of the MFIs' SE in all countries not including the impact of competition freedom. Source: own research

\begin{tabular}{|l|l|l|l|l|l|l|}
\hline \multirow{2}{*}{ Variable } & Model 1 & Model 2 \\
\cline { 2 - 7 } & POLS & FEM & REM & POLS & FEM & REM \\
\hline Constant & $0.176 \mathrm{c}$ & $-5.041 \mathrm{a}$ & $-0.974 \mathrm{~b}$ & $-1.353 \mathrm{a}$ & $-7.972 \mathrm{a}$ & $-4.302 \mathrm{a}$ \\
\hline & $-(0.090)$ & $-(1.078)$ & $-(0.485)$ & $-(0.483)$ & $-(0.573)$ & $-(0.791)$ \\
\hline MFI's Specific Determinant \\
\hline LnTA & $-0.114 \mathrm{a}$ & 0.074 & $-0.061 \mathrm{c}$ & $-0.084 \mathrm{a}$ & $-0.095 \mathrm{a}$ & -0.043 \\
\hline & $-(0.005)$ & $-(0.092)$ & $-(0.032)$ & $-(0.017)$ & $-(0.021)$ & $-(0.029)$ \\
\hline LnAGE & $0.051 \mathrm{a}$ & 0.589 & 0.151 & 0.038 & $-0.626 \mathrm{a}$ & -0.004 \\
\hline & $-(0.011)$ & $-(0.411)$ & $-(0.113)$ & $-(0.053)$ & $-(0.168)$ & $-(0.096)$ \\
\hline LnROA & $0.577 \mathrm{a}$ & $1.259 \mathrm{a}$ & $0.492 \mathrm{a}$ & $0.564 \mathrm{a}$ & $1.230 \mathrm{~b}$ & $0.805 \mathrm{a}$ \\
\hline & $-(0.031)$ & $-(0.482)$ & $-(0.185)$ & $-(0.075)$ & $-(0.523)$ & $-(0.131)$ \\
\hline
\end{tabular}




\begin{tabular}{|c|c|c|c|c|c|c|}
\hline \multirow[t]{2}{*}{ LnDTE } & $-0.033 b$ & 0.022 & -0.017 & $-0.057 \mathrm{c}$ & 0.046 & -0.017 \\
\hline & $-(0.016)$ & $-(0.059)$ & $-(0.059)$ & $-(0.034)$ & $-(0.039)$ & $-(0.055)$ \\
\hline \multicolumn{7}{|c|}{ Macroeconomics Determinants } \\
\hline \multirow[t]{2}{*}{ LnGDP } & & & & $0.164 \mathrm{a}$ & $0.681 \mathrm{a}$ & $0.425 \mathrm{a}$ \\
\hline & & & & $-(0.044)$ & $-(0.061)$ & $-(0.077)$ \\
\hline \multirow[t]{2}{*}{ LnCPI } & & & & $-0.084 a$ & 0.003 & $0.029 \mathrm{c}$ \\
\hline & & & & $-(0.027)$ & $-(0.004)$ & $-(0.017)$ \\
\hline $\mathrm{R}^{2}$ & 0.523 & 0.712 & 0.017 & 0.107 & 0.992 & 0.044 \\
\hline Adj $R^{2}$ & 0.521 & 0.663 & 0.013 & 0.103 & 0.991 & 0.04 \\
\hline F-statistic & $318.786 a$ & $14.516 \mathrm{a}$ & $4.947 \mathrm{a}$ & $23.287 \mathrm{a}$ & $760.664 a$ & $9.012 \mathrm{a}$ \\
\hline BPLM $\chi^{2}$ & \multicolumn{3}{|l|}{$1375.820 \mathrm{a}$} & \multicolumn{3}{|c|}{$1292.430 \mathrm{a}$} \\
\hline Hausman $\chi^{2}$ & \multicolumn{3}{|l|}{$82.023 \mathrm{a}$} & \multicolumn{3}{|c|}{$124.348 \mathrm{a}$} \\
\hline Model Used & \multicolumn{3}{|l|}{ FEM } & \multicolumn{3}{|l|}{ FEM } \\
\hline No. of Obs. & 1169 & 1169 & 1169 & 1169 & 1169 & 1169 \\
\hline
\end{tabular}

Note: a, b, c indicate significance at $1 \%, 5 \%$ and $10 \%$ levels respectively.

Figures in parentheses () are standard errors.

Tab. 8 - Regression result of the MFIs' SE in all countries including components regarding the impact of competition freedom on business and monetary freedom. Source: own research

\begin{tabular}{|c|c|c|c|c|c|c|}
\hline \multirow[t]{2}{*}{ Variable } & \multicolumn{3}{|l|}{ Model 1} & \multicolumn{3}{|l|}{ Model 2} \\
\hline & POLS & FEM & REM & POLS & FEM & REM \\
\hline \multirow[t]{2}{*}{ Constant } & $-4.080 \mathrm{a}$ & $-12.830 \mathrm{a}$ & $-5.228 \mathrm{a}$ & $-29.903 a$ & -0.246 & $-10.344 b$ \\
\hline & $-(0.961)$ & $-(1.725)$ & $-(0.962)$ & $-(5.978)$ & $-(4.562)$ & $-(4.242)$ \\
\hline \multicolumn{7}{|c|}{ MFI's Specific Determinants } \\
\hline \multirow[t]{2}{*}{ Ln'TA } & $-0.077 \mathrm{a}$ & $-0.136 c$ & -0.038 & $-0.087 \mathrm{a}$ & -0.101 & -0.044 \\
\hline & $-(0.017)$ & $-(0.079)$ & $-(0.029)$ & $-(0.016)$ & $-(0.076)$ & $-(0.029)$ \\
\hline \multirow[t]{2}{*}{ LnAGE } & 0.039 & $-1.065 b$ & 0.008 & -0.005 & $-0.632 c$ & -0.011 \\
\hline & $-(0.052)$ & $-(0.411)$ & $-(0.096)$ & $-(0.053)$ & $-(0.363)$ & $-(0.096)$ \\
\hline \multirow[t]{2}{*}{ LnROA } & $0.554 \mathrm{a}$ & $1.762 \mathrm{~b}$ & $0.793 \mathrm{a}$ & $0.378 \mathrm{a}$ & $1.763 \mathrm{~b}$ & $0.752 \mathrm{a}$ \\
\hline & $-(0.075)$ & $-(0.845)$ & $-(0.130)$ & $-(0.084)$ & $-(0.843)$ & $-(0.136)$ \\
\hline \multirow[t]{2}{*}{ LnDTE } & $-0.164 a$ & -0.043 & -0.046 & $-0.056 c$ & -0.051 & -0.018 \\
\hline & $-(0.047)$ & $-(0.100)$ & $-(0.057)$ & $-(0.034)$ & $-(0.100)$ & $-(0.055)$ \\
\hline \multicolumn{7}{|c|}{ Macroeconomics Determinants } \\
\hline \multirow[t]{2}{*}{ LnGDP } & $0.206 \mathrm{a}$ & $2.312 \mathrm{a}$ & $0.424 \mathrm{a}$ & $0.203 \mathrm{a}$ & $2.288 \mathrm{a}$ & $0.418 \mathrm{a}$ \\
\hline & $-(0.046)$ & $-(0.264)$ & $-(0.077)$ & $-(0.045)$ & $-(0.244)$ & $-(0.077)$ \\
\hline \multirow[t]{2}{*}{ LnCPI } & $-0.067 b$ & $0.063 \mathrm{a}$ & $0.032 \mathrm{c}$ & -0.036 & $0.047 \mathrm{a}$ & $0.037 \mathrm{~b}$ \\
\hline & $-(0.027)$ & $-(0.017)$ & $-(0.017)$ & $-(0.029)$ & $-(0.018)$ & $-(0.017)$ \\
\hline
\end{tabular}




\begin{tabular}{|l|l|l|l|l|l|l|}
\hline LnBusiFree & $0.685 \mathrm{a}$ & $-0.488 \mathrm{~b}$ & $0.238 \mathrm{c}$ & & & \\
\hline & $-(0.209)$ & $-(0.188)$ & $-(0.141)$ & & & \\
\hline LnMoneFree & & & & $6.557 \mathrm{a}$ & $-3.728 \mathrm{a}$ & 1.421 \\
\hline & & & & $-(1.369)$ & $-(1.135)$ & $-(0.985)$ \\
\hline & & & & & & \\
\hline $\mathrm{R}^{2}$ & 0.116 & 0.736 & 0.047 & 0.125 & 0.737 & 0.046 \\
\hline Adj R ${ }^{2}$ & 0.11 & 0.69 & 0.041 & 0.119 & 0.691 & 0.04 \\
\hline F-statistic & $21.664 \mathrm{a}$ & $15.997 \mathrm{a}$ & $8.107 \mathrm{a}$ & $23.617 \mathrm{a}$ & $16.085 \mathrm{a}$ & $7.983 \mathrm{a}$ \\
\hline BPLM $\chi^{2}$ & $1270.450 \mathrm{a}$ & \multicolumn{5}{|l|}{} \\
\hline Hausman $\chi^{2}$ & $131.472 \mathrm{a}$ & & $1233.930 \mathrm{a}$ & & \\
\hline Model Used & FEM & & & & & \\
\hline No. of Obs. & 1169 & 1169 & 1169 & 1169 & 1169 & 1169 \\
\hline
\end{tabular}

Note: a, b, c indicate significance at $1 \%, 5 \%$ and $10 \%$ levels respectively.

Figures in parentheses () are standard errors.

Tab. 9 - Regression result of the MFIs' SE in all countries including components regarding the impact of competition freedom on investment and financial freedom. Source: own research

\begin{tabular}{|c|c|c|c|c|c|c|}
\hline \multirow[t]{2}{*}{ Variable } & \multicolumn{3}{|l|}{ Model 1} & \multicolumn{3}{|l|}{ Model 2} \\
\hline & POLS & FEM & REM & POLS & FEM & REM \\
\hline \multirow[t]{2}{*}{ Constant } & 0.972 & $-12.011 \mathrm{a}$ & $-1.622 c$ & $-4.994 a$ & $-18.137 \mathrm{a}$ & $-3.613 a$ \\
\hline & $-(0.985)$ & $-(1.624)$ & $-(0.912)$ & $-(0.747)$ & $-(1.543)$ & $-(0.799)$ \\
\hline \multicolumn{7}{|c|}{ MFI's Specific Determinants } \\
\hline \multirow[t]{2}{*}{ LnTA } & $-0.084 a$ & -0.094 & -0.039 & $-0.084 a$ & $-0.214 \mathrm{a}$ & -0.034 \\
\hline & $-(0.017)$ & $-(0.073)$ & $-(0.029)$ & $-(0.016)$ & $-(0.070)$ & $-(0.028)$ \\
\hline \multirow[t]{2}{*}{ LnAGE } & 0.035 & $-0.702 b$ & -0.021 & -0.021 & $-1.901 \mathrm{a}$ & -0.01 \\
\hline & $-(0.052)$ & $-(0.354)$ & $-(0.096)$ & $-(0.053)$ & $-(0.350)$ & $-(0.093)$ \\
\hline \multirow[t]{2}{*}{ LnROA } & $0.556 a$ & $2.131 b$ & $0.830 \mathrm{a}$ & $0.318 \mathrm{a}$ & $2.354 \mathrm{a}$ & $0.983 \mathrm{a}$ \\
\hline & $-(0.075)$ & $-(0.825)$ & $-(0.131)$ & $-(0.084)$ & $-(0.782)$ & $-(0.133)$ \\
\hline \multirow[t]{2}{*}{ LnDTE } & -0.046 & -0.033 & 0.001 & -0.047 & -0.051 & -0.012 \\
\hline & $-(0.034)$ & $-(0.098)$ & $-(0.055)$ & $-(0.034)$ & $-(0.093)$ & $-(0.053)$ \\
\hline \multicolumn{7}{|c|}{ Macroeconomics Determinants } \\
\hline \multirow[t]{2}{*}{ LnGDP } & $0.165 a$ & $2.200 \mathrm{a}$ & $0.469 \mathrm{a}$ & $0.140 \mathrm{a}$ & $4.143 \mathrm{a}$ & $0.526 a$ \\
\hline & $-(0.044)$ & $-(0.216)$ & $-(0.077)$ & $-(0.044)$ & $-(0.262)$ & $-(0.077)$ \\
\hline \multirow[t]{2}{*}{ LnCPI } & $-0.114 a$ & 0.016 & -0.008 & 0.001 & -0.007 & 0.008 \\
\hline & $-(0.029)$ & $-(0.018)$ & $-(0.017)$ & $-(0.030)$ & $-(0.017)$ & $-(0.017)$ \\
\hline \multicolumn{7}{|c|}{ Competition Freedom Determinants } \\
\hline \multirow[t]{2}{*}{ LnInvestFree } & $-0.586 a$ & $-0.976 \mathrm{a}$ & $-0.772 \mathrm{a}$ & & & \\
\hline & $-(0.216)$ & $-(0.129)$ & $-(0.127)$ & & & \\
\hline LnFinaFree & & & & $1.055 \mathrm{a}$ & $-1.909 \mathrm{a}$ & $-0.439 \mathrm{a}$ \\
\hline
\end{tabular}




\begin{tabular}{|c|c|c|c|c|c|c|}
\hline & & & & $-(0.167)$ & $-(0.144)$ & $-(0.112)$ \\
\hline $\mathrm{R}^{2}$ & 0.113 & 0.748 & 0.071 & 0.137 & 0.774 & 0.054 \\
\hline Adj R² & 0.108 & 0.705 & 0.065 & 0.132 & 0.734 & 0.048 \\
\hline F-statistic & $21.118 \mathrm{a}$ & $17.100 \mathrm{a}$ & $12.609 \mathrm{a}$ & $26.346 \mathrm{a}$ & $19.661 \mathrm{a}$ & $9.415 \mathrm{a}$ \\
\hline BPLM $\chi^{2}$ & \multicolumn{3}{|c|}{$1329.410 \mathrm{a}$} & \multicolumn{3}{|c|}{$1047.230 \mathrm{a}$} \\
\hline Hausman $\chi^{2}$ & \multicolumn{3}{|c|}{$147.412 \mathrm{a}$} & \multicolumn{3}{|c|}{$305.142 \mathrm{a}$} \\
\hline Model Used & \multicolumn{3}{|c|}{ FEM } & \multicolumn{3}{|c|}{ FEM } \\
\hline No. of Obs. & 1169 & 1169 & 1169 & 1169 & 1169 & 1169 \\
\hline
\end{tabular}

Note: a, b, c indicate significance at $1 \%, 5 \%$ and $10 \%$ levels respectively.

Figures in parentheses () are standard errors.

\section{CONCLUSIONS}

The main objective of this paper is to identify the effect of two dimensions of competition freedom, regulatory efficiency and market openness, on the efficiency of MFIs in both financial and social ways. This study has also attempted to investigate the potential of MFIs, specific characteristics and macroeconomics that may influence the efficiency of MFIs. In this study, a total of 167 pieces of data were collected from MFIs of the five selected nations of Cambodia, Indonesia, Malaysia, Philippines and Thailand from 2011 to 2017. Overall, the level of financial efficiency in the MFIs is significantly higher than social efficiency. On one hand, the results show that size (lnTA), years of operation (LnAGE) of MFIs have a statistically significant positive and negative relationship with financial and social efficiency, respectively. Meanwhile, the profitability (lnROA) provides a significant influence only on social efficiency, with leverage (LnDTE) significant for financial efficiency only. On the other hand, the macroeconomics factors (lnGDP and LnCPI) have a significant positive relationship with both financial and social efficiency.

In examining the impact of competition freedom, the result shows that business freedom and monetary freedom negatively influenced social efficiency. The greater ability to establish and operate a new business may increase the MFIs' entry barriers. Therefore, it may increase the level of competition and dampen the efficiency level of MFIs. Increasing competition in the MFIs sector reduces MFIs' social efficiency. Meanwhile, as for the monetary freedom, the result favors intervention from the government, which it is required to ensure the reliability and stability of monetary policy important for MFIs when generating wealth and thus increasing their income and their ability to assist a higher number of the disadvantaged.

Furthermore, this research revealed that investment freedom shows a positive relationship with financial efficiency, which indicates a higher investment freedom and leads to higher MFIs' financial efficiency. This activity allows the MFIs to be independent in regard to choosing the most favorable investment portfolio without any intervention from the authority, which may enhance their proficiencies for the future, mainly gaining experience in forming strategies to maximize their return form investments. Nevertheless, investment freedom was shown to be significantly negative for social efficiency since the investors have more options to invest based on their individual preferences. Hence more investment choices appear, which tends to decrease the number of potential investors for MFIs. 
In addition, a positive impact of financial freedom on the financial efficiency supports the argument that a less restricted environment can create more competitive policies and can then help in increasing the efficiency of MFIs. This financial freedom, however, is significantly negative for social efficiency, and suggests that fewer subsidies by the government lead to a lower MFIs' social efficiency.

This study thus identifies what MFIs should focus on: creating awareness of their main objective, which is securing both financial and social efficiency while delivering financial services to the poor. According to the results of this research, MFIs can obtain more information and increased understanding of how well the variables contribute to the efficiency of MFIs in terms of different variables. In addition, MFIs may use the results of this study to identify the particular variables they need to focus on to enhance both their financial and social efficiency. For instance, the result shows how MFIs' total asset can affect the microfinance efficiency financially and socially; hence, MFIs can take necessary action to ensure the balance of both types of efficiency.

The governments or policymakers can adapt the empirical findings from this study to formulate policies and strategies so that MFIs have a better platform to provide better financial services as well as outreach to a higher number of poor people. Moreover, policymakers can also receive some informed suggestions on how policy can be improved to reach financial and social efficiency. While improving the policy, MFIs become accessible to the poor. Hence, it allows a larger number of people or poor people enjoy the financial services provided by MFIs.

For investors, this study will provide a view on the efficiency level and performance of MFIs in the selected countries. Since investors concern the performance of MFIs before making investment decisions, they can receive MFIs' overall performance through this study and then decide whether to invest or not. Since both financial and social efficiency are included in this study, hence investors can decide to invest in MFIs with higher financial efficiency or higher social efficiency. Therefore, by using this study, investors can choose the best MFIs to invest and benefit their portfolio.

For researchers, this study creates an interest in the same industry, which is MFIs. They can improve and extend this study by adopting the suggestions given in this study. Future studies may be conducted overcoming the limitations faced by this study. Besides, the empirical results in this study are useful to academicians to fill scholarly gaps. Moreover, the empirical findings of this study show potential internal and external determinants that affect the efficiency level of MFIs in both financial and social aspects. The future researchers can use this study as a guide to explore more potential determinants that affect MFIs' financial and social efficiency. The result of the effect of competition freedom towards MFIs' efficiency also contributes to a new area and explores more possible determinants in the literature.

\section{Acknowledgements}

We would like to thank the editors and anonymous referees of the journal for constructive comments and suggestions, which have significantly helped to improve the contents of the paper. Furthermore, special thanks to 1) Universiti Putra Malaysia Grant Putra Vot No. 9632100 sponsored by Universiti Putra Malaysia; 2) Fundamental Research Grant Scheme (FRGS) Vot No. FRGS/1/2015/SS01/UPM/02/1 sponsored by Malaysian Ministry of Higher Education 3) Universiti Putra Malaysia Grant IPM Vot No. 9473700 sponsored by Universiti Putra Malaysia and Education 4) Universiti Putra Malaysia Grant IPS Vot No. 9651500 sponsored by Universiti Putra Malaysia as organizations that funded our research. The usual caveats apply. 


\section{References}

1. Abdulai, A., \& Tewari, D. D. (2016). Efficiency of Microfinance Institutions in Sub - Saharan Africa: A Stochastic Frontier Approach. Ghana Journal of Development Studies, 13 (2), 117-139. https://doi.org/10.4314/gjds.v13i2.7

2. Abrar, A., \& Javaid, A. Y. (2016). The Impact Of Capital Structure On The Profitability of Microfinance Institutions. South Asian Journal of Management, 10 (1), 21-37. https://doi. $\operatorname{org} / 10.21621 /$ sajms.2016101.03

3. Al-Gasaymeh, A. (2018). Economic Freedom, Country Risk and Cost Efficiency in Jordan and the GCC Countries. Global Busines Review, 21(1), 1-17 https://doi. org $/ 10.1177 / 0972150917749292$

4. Ananya, R. (2016.). Poverty Capital: Microfinance And The Making of Development. Singapore Journal of Tropical Geography, 33 (2), 270-271. https://doi.org/10.1111/j.1467-9493.2012.00462.x

5. Abdelkader, B. I., \& Mansouri, F. (2019). Performance of Microfinance Institutions in the MENA Region: A Comparative Analysis. International Journal of Social Economics, 4 (1), 47-65. https://doi.org/10.1108/ijse-06-2017-0242

6. Chortareas, G. E., Girardone, C., \& Ventouri, A. (2013). Financial Freedom and Bank Efficiency : Evidence from the European Union. Journal of Banking \& Finance, 37 (4), 1223 1231. https://doi.org/10.1016/j.jbankfin.2012.11.015

7. Coelli, T., Prasada, R. \& Battese, G. (1998). An Introduction to Efficiency and Productivity Analysis, Kluwer Academic Publishers, Boston, Ma. https://doi.org/10.1007/b136381

8. Demirgüneş, K. \& Üçler, G. (2015). Inter Relationship between Profitability, Growth, and Size: Case of Turkey. Journal of Business Economics \& Finance, 4 (4), 659-678. https://doi. org/10.17261/pressacademia.2015414534

9. De Haan, J., \& Sturm, J. E. (2000). On the Relationship between Economic Freedom and Economic Growth. European Journal of Political Economy, 16 (2), 215-241. https://doi. org/10.1016/S0176-2680(99)00065-8

10. Donou-Adonsou, F., \& Sylwester, K. (2017). Growth Effect of Banks and Microfinance: Evidence from Developing Countries. Quarterly Review of Economics and Finance, 64, 44-56. https://doi.org/10.1016/j.qref.2016.11.001

11. Dorfleitner, G., Priberny, C., \& Röhe, M. (2017). Why do Microfinance Institutions Fail Socially? A Global Empirical Examination. Finance Research Letters, 22, 81-89. https://doi. org/10.1016/j.frl.2016.12.027

12. Gaganis, C. (2016). Assessing the overall Performance of Microfinance Institutions. International Journal of Banking, Accounting \& Finance, 7 (1), 52-83. https://doi.org/10.1504/ ijbaaf.2016.079165

13. Grmanová, E., \& Ivanová, E. (2018). Efficiency of Banks in Slovakia: Measuring by DEA Models. Journal of International Studies, 11 (1), 257-272. https://doi.org/10.14254/2071$8330.2018 / 11-1 / 20$

14. Hermes, N., Lensink, R., \& Meesters, A. (2018). Financial Development And The Efficiency Of Microfinance Institutions. Research Handbook on Small Business Social Responsibility, 177-205. Edward Elgar Publishing Limited, the Lypiatts, Gheltenham, UK. https://doi. org/10.4337/9781784711825.00017 
15. Hussain, H.I., Abidin, I.S.Z., Ali, A. \& Kamarudin, F. (2018).Debt Maturity and Family Related Directors: Evidence from a Developing Market. Polish Journal of Management Studies, 18 (2), 118-134. https://doi.org/10.17512/pjms.2018.18.2.10

16. Imai, K., Gaiha, R., Thapa, G., Annim, S. K., \& Gupta, A. (2011). Performance of Institutions: A Macroeconomic And Institutional Perspective. Economic Discussion Paper Series, 1-34. Research Institute for Economics \& Business Administration, Kobe University. http://hummedia.manchester.ac.uk/schools/soss/economics/discussionpapers/EDP-1116.pdf

17. Kamarudin, F., Nordin, B. A. A., Muhammad, J. \& Hamid, M. A. A. (2014). Cost, Revenue and Profit Efficiency of Islamic and Conventional Banking Sector: Empirical Evidence from Gulf Cooperative Council Countries. Global Business Review, 15 (1), 1-24. https://doi. org/10.1177/0972150913515579

18. Lebovics, M., Hermes, N., \& Hudon, M. (2016). Are Financial and Social Efficiency Mutually Exclusive? A Case Study of Vietnamese Microfinance Institutions. Annals of Public And Cooperative Economics, 87 (1), 55-77. https://doi.org/10.1111/apce.12085

19. Liu, R (2019). Comparison of Bank Efficiencies between the US and Canada: Evidence Based on SFA and DEA. Journal of Competitiveness, 11 (2), 113-129. https://doi.org/10.2139/ $\operatorname{ssrn} .3317196$

20. Louis, P., Seret, A., \& Baesens, B. (2013). Financial Efficiency and Social Impact of Microfinance Institutions using Self-Organizing Maps. World Development, 46, 197-210. https:// doi.org/10.1016/j.worlddev.2013.02.006

21. Mia, M. A., \& Soltane, B. I. (2016). Productivity and its Determinants in Microfinance Institutions (MFIs): Evidence from South Asian Countries. Economic Analysis \& Policy, 51, 32-45. https://doi.org/10.1016/j.eap.2016.05.003

22. Nanayakkara, G. (2017). Interaction and Higher Order Effects of Factors Affecting the Performance of Microfinancing Institutions. International Journal of Social Economics, 44(7), 900-920. https://doi.org/10.1108/ijse-12-2014-0251

23. Palečková, I. (2015). Banking Efficiency in Visegrad Countries: A Dynamic Data Envelopment Analysis. Acta Universitatis Agriculturae et Silviculturae Mendelianae Brunensis, 63 (6), 2085-2091. https://doi.org/10.11118/actaun201563062085

24. Quayes, S. (2012). Depth of Outreach and Financial Sustainability of Microfinance Institutions. Applied Economics, 44 (26), 3421-3433. https://doi.org/10.1080/00036846.2011.57 7016

25. Sarpong-Kumankoma, E., Abor, J., Aboagye, A. Q. Q., \& Amidu, M. (2017). Freedom, Competition and Bank Efficiency in Sub-Saharan Africa. International Journal of Law \& Management, 59 (6), 1359-1380. https://doi.org/10.1108/ijlma-11-2016-0142

26. Sufian, F., \& Habibullah, M. S. (2014). Economic Freedom and Bank Efficiency: Does Ownership and Origins Matter? Journal of Financial Regulation And Compliance. 22 (3), 174-207. https://doi.org/10.1108/jfrc-01-2013-0001

27. Sufian, F. \& Kamarudin, F. (2014). The Impact of Ownership Structure on Bank Productivity and Efficiency: Evidence from Semi-Parametric Malmquist Productivity Index. Cogent Economics and Finance, 2 (1), 1-27. https://doi.org/10.1080/23322039.2014.932700 
28. Sufian, F., \& Kamarudin, F. (2015). Determinants of Revenue Efficiency of Islamic Banks. International Journal of Islamic and Middle Eastern Finance and Management, 8 (1), 36-63. https://doi. org/10.1108/imefm-12-2012-0114

29. Sufian, F., \& Zulkhibri, M. (2015). The Nexus Between Economic Freedom and Islamic Bank Profitability in the Mena Banking Sectors. Global Business Review. 16 (5), 58-81. https://doi. org/10.1177/0972150915601256

30. White, H. J. (1980). A Heteroskedasticity-Consistent Covariance Matrix Estimator and a Direct Test for Heteroskedasticity. Econometrica, 48 (4), 817-838. https://doi. org/10.2307/1912934

31. Wijesiri, M., Yaron, J., \& Meoli, M. (2017). Assessing The Financial And Outreach Efficiency Of Microfinance Institutions: Do Age And Size Matter? Journal Of Multinational Financial Management, 40, 63-76. https://doi.org/10.1016/j.mulfin.2017.05.004

32. Zainal, N., Nassir, A. M., Kamarudin, F., Hook, L. S. Sufian, F., Hussain, H. I. (2019). Social Role of Microfinance Institutions in Poverty Eradication: Evidence from ASEAN-5 Countries. International Journal of Innovation, Creativity and Change, 5 (2), 1551-1576. https://www. ijicc.net/images/Vol5iss2_/89_Zainal_P1551_2019R.pdf

\section{Contact information}

Assoc. Prof. Hafezali Iqbal Hussain, PhD

Taylor's University, Taylor's Business School

Taylor's Lakeside Campus

Faculty of Business and Law

Visiting Professor, University of Economics and

Human Sciences Okopowa

Malaysia

E-mail: hafezali.iqbalbussain@taylors.edu.my

ORCID: 0000-0002-9381-7743

Assoc. Prof. Sebastian Kot, PhD*

Czestochowa University of Technology, The Management Faculty

North-West University, Faculty of Economic and

Management Sciences

Poland

E-mail:sebastian.kot@wr:pcr:pl

ORCID: 0000-0002-8272-6918
Dr. Fakarudin Kamarudin, PhD

Universiti Putra Malaysia

Faculty of Economics and Management

Department of Accounting and Finance

Malaysia

E-mail:Fakarudin@upm.edu.my

ORCID: 0000-0001-8180-1173

Wong Che Mun

Universiti Putra Malaysia

Faculty of Economics and Management

Department of Accounting and Finance

Malaysia

E-mail: chemun95@gmail.com

ORCID: 000-0002-7545-8724 